\title{
IS ENVIRONMENTAL SUSTAINABILITY A STRATEGIC PRIORITY FOR LOGISTICS SERVICE PROVIDERS?
}

Pietro Evangelista ${ }^{a}$, Claudia Colicchia $^{b}$, Alessandro Creazza $^{c}$

${ }^{a}$ Institute for Research on Innovation and Services for Development (IRISS), National Research Council (CNR), Via G. Sanfelice, 8, 80134 Naples, Italy, p.evangelista@unina.it

${ }^{\mathrm{b}}$ The University of Hull, Hull University Business School, Logistics Institute, Cottingham Road, Hull, HU6 7RX, United Kingdom, c.colicchia@hull.ac.uk

'(corresponding author)The University of Hull, Hull University Business School, Logistics Institute, Cottingham Road, Hull, HU6 7RX, United Kingdom, Tel: 01482 347586, a.creazza@hull.ac.uk 


\title{
IS ENVIRONMENTAL SUSTAINABILITY A STRATEGIC PRIORITY FOR LOGISTICS SERVICE PROVIDERS?
}

\begin{abstract}
Despite an increasing number of third-party logistics service providers (3PLs) regard environmental sustainability as a key area of management, there is still great uncertainty on how 3PLs implement environmental strategies and on how they translate green efforts into practice. Through a multiple case study analysis, this paper explores the environmental strategies of a sample of medium-sized 3PLs operating in Italy and the UK, in terms of environmental organisational culture, initiatives, and influencing factors. Our analysis shows that, notwithstanding environmental sustainability is generally recognised as a strategic priority, a certain degree of diversity in the deployment of environmental strategies still exists. This paper is original since the extant literature on green strategies of 3PLs provides findings predominantly from a single country perspective and mainly investigates large/multinational organizations. It also provides indications to help managers of medium-sized 3PLs in positioning their business. This is particularly meaningful in the 3PL industry, where medium-sized organizations significantly contribute to the generated turnover and market value.
\end{abstract}

\section{KEYWORDS}

Environmental Strategy, Environmental Sustainability Practices, Influencing Factors, Logistics Service Providers, Case Study Analysis 


\section{INTRODUCTION}

Due to the continuous degradation of the natural environment, climate change and global warming, environmental sustainability issues have emerged as key areas in the management of companies. Increasing customer demand for ecological products and services, tightening environmental regulations and growing demand for greater corporate social responsibility have become the main drivers for companies to undertake green strategies (Gotschol et al., 2014; Min and Kim, 2012).

The transport and logistics industry is a key component of trade and a major contributor to economic growth in many countries. However, logistics activities come along with severe negative environmental impacts, particularly caused by freight transport. In the EU, greenhouse gases (GHG) emissions of the transport sector increased at a higher rate in comparison with other industries over the last decades (European Commission, 2014). The World Economic Forum (2009) calculated that the freight transport and logistics industry is responsible for about 5.5\% (2,500 megatonnes) of the GHG emissions at global level and road freight is a major contributor of this footprint (WEF, 2009). This scenario should accelerate the adoption of environmental strategies by third-party logistics service providers (3PLs) (McKinsey, 2013) and environmental sustainability should be considered a priority and a source of competitive advantage (McWilliams and Siegel, 2011).

The environmental strategy of a company may be defined as the environmental organisational culture, the set of green initiatives and factors (both internal and external) influencing their implementation (Wu et al., 2014; Argon-Correa et al., 2008). Despite an increasing number of 3PLs are regarding environmental sustainability as an opportunity for improving competitiveness and obtaining economic benefits (Fürst and Oberhofer, 2012), there is still a great deal of uncertainty on how 3PLs implement environmental strategies and how they translate green efforts into practice (Lin and Ho, 2008). From the research viewpoint, this is reflected by a number of studies that have highlighted the hesitant behaviour of logistics companies in embracing environmental sustainability (Wolf and Seuring, 2010). In addition, the extant literature on green strategies of 3PLs is predominantly focused on large companies (Lieb and Lieb, 2010a) while the green attitude of medium sized 3PLs is unclear and under-researched (Oberhofer and Deplinger, 2014). Finally, most of the studies conducted on environmental sustainability in the logistics service industry provides findings from a single country perspective (see for example Maas et al. (2014) based on the German 3PL market and the study of Lun et al. (2015) presenting empirical data on the practices adopted by 3PLs operating in Hong Kong). There is a scarcity of comparative research providing evidences collected from 3PLs operating in different countries.

Given this background, the aim of this paper is to explore environmental strategies in a sample of medium sized 3PLs operating in Italy and the UK. Following the above definition, the paper specifically analyses the environmental organisational culture, green initiatives, and influencing factors (drivers and barriers). Taking into account the role of medium sized 3PLs in the Italian and UK logistics service markets, the paper is focused on these companies. Moreover given the importance of the Italian and UK logistics service markets in the European competitive scenario, the paper provides evidences based on a cross country analysis that could be of help in understanding differences and commonalities of green strategies adopted by 3PLs operating in varied contexts.

This paper is organised as follows. Section 2 presents a literature review providing the theoretical basis of the work and allowing for the identification of research questions. 
Section 3 summarises the adopted methodology. The main findings are presented in Section 4 and discussed in Section 5. Conclusions and implications for research and practice are drawn in Section 6.

\section{LITERATURE REVIEW AND RESEARCH QUESTIONS}

On the basis of the definition of environmental strategy provided in the previous section, the literature review focuses on three areas: environmental organisational culture, green initiatives and influencing factors.

\subsection{Environmental organisational culture}

The literature on green logistics and supply chain management (SCM) highlighted that organisational structures, climates, and cultures have an impact on the adoption of environmental sustainability practices (Zhu et al., 2008). In fact, organizations need to develop an organizational culture that fosters collaboration and proactive attitude among staff members at all levels to be able to turn sustainable strategies into practice (Wan Ahmad et al., 2016). Nevertheless, the literature on 3PLs has seldom focused on these aspects and the number of contributions in this area is relatively small. Rossi et al. (2013) proposed a framework to explore the environmental sustainability culture in the 3PL industry in terms of importance attributed to environmental sustainability, presence of an explicit environmental strategy, incorporation of it into the corporate strategy and primary and secondary responsibility for environmental issues within the companies. According to the authors, the primary responsibility includes the ownership of the process and the liability for setting policies and objectives, while the secondary responsibility involves the execution and reporting on environmental initiatives. Lin and Ho (2008) argued that embracing environmental sustainability by 3PLs requires a fundamental shift in the firms' culture. The survey they conducted found that the intention to adopt green innovations is positively associated to organisational capabilities and encouragement, the quality of human resources and the accumulation of green-related knowledge. Lieb and Lieb (2010b) surveyed a sample of 20 CEOs of large 3PLs operating in North America to understand the reasons for 3PLs being involved in environmental sustainability practices. Many of the surveyed 3PLs established formal programs in the area, but they also developed formal green/environmental sustainability statements, and appointed key individuals to lead related initiatives. These companies have collectively taken numerous steps to pursue green/environmental sustainability goals and "green" is a part of their corporate culture. This had raised environmental awareness within their organisations. Lin and Ho (2011) analysed the environmental practices in a sample of Chinese 3PLs and they found that organisational support, especially from top management, is essential in advancing green practice adoption as it gives employees motivation and resources to successfully implement environmental actions. Lammgard (2012) found that organisations' employees need a sufficient level of knowledge on environmental issues to meet requirements from external partners, e.g. customers. She concluded that embracing environmental sustainability from a strategic perspective requires structural changes and time. The work presented by Colicchia at al. (2013) also focused on the management of human resources within the organisation. They found that environmental training programmes at all levels are implemented and this has a critical importance in the achievement of companies' sustainability targets. Isaksson and Huge-Brodin (2013) also considered aspects such as organisational, personal, and cultural issues. They argued that employees' involvement when companies adopt green initiatives seems to be a significant factor. In relation to this, they found two 
different drivers to develop green initiatives in 3PLs: employees' initiatives (bottomup approach) or management and board involvement (top-down approach). According to their study, the implementation of environmental actions follows two main trajectories: the first entails a broad approach to create a common awareness within the company (broad penetration); the second implies the allocation of different roles to different departments (functional specialisation). Finally the link between environmental issues and 3PLs' operations has been investigated by Pålsson and Kovács (2014). Their findings indicate that environmental sustainability culture should be spread in the entire organisation and it should be reflected in the overall corporate strategy. A number of interesting issues may be derived from the analysis of the above papers. Firstly, there are no specific papers investigating environmental culture and organisational issues in the 3PL literature. All the studies considered devote little attention to organisational aspects. Secondly, most of these studies focus on the improvement of the quality of human resources involved in environmental actions, mainly through training initiatives and programmes. Thirdly, very few works analysed the link between the environmental strategy in the context of the overall corporate strategy and how the responsibilities for environmental management are organised and distributed among companies' functions and departments. Finally, most of the reviewed works focused on large logistics service providers. The combination of these arguments leads to inform the development of the first research question:

RQ1) How do 3PLs embed environmental sustainability in their culture and organisation?

\subsection{Initiatives to reduce the environmental impact of transport and logistics services}

Green initiatives may be defined as the set of actions and decisions necessary to mitigate the negative impact on the environment deriving from the activities carried out by a company (Klassen and McLaughlin, 1996). According to Zhu et al. (2007), the magnitude of green initiatives depends on the type and scope of the actions adopted by the companies participating in the supply chain processes. In the field of 3PL research several studies deal with the initiatives undertaken by logistics companies to minimise the environmental impact of their operations. Rondinelli and Berry (2000) emphasize the role of multimodal transport and provide a conceptual framework for understanding the interactions between multimodal transport activities and their impact on the environment. The study carried out by Lammgard (2012) focused on intermodal road-rail transport services. Results indicate that the role of customers and competitors is crucial in driving the adoption of intermodal arrangements for improving environmental performance. This seems especially valid for large organizations that are able to directly engage with customers for designing their environmental strategies through "customer-oriented projects", and for which time, reliability and cost efficiency of intermodal services act as enabling factors. Lieb and Lieb (2010a) noted that despite the global recession, many large 3PLs increased their commitment to adopt environmental sustainability initiatives. On the basis of two surveys carried out on 40 CEOs of US large 3PLs, the authors classified the green initiatives adopted by the surveyed companies into four categories: i) administrative (e.g. setting specific sustainability goals for individual operating units, establishing committees to oversee company sustainability efforts), ii) analytical (e.g. investing in evaluation software, improving control of a company's service providers through the use of environmental checklists, benchmarking a 
company's carbon footprint against other 3PLs), iii) transportation-related (e.g. alternative fuels, purchasing more fuel-efficient vehicles, reducing vehicles' mileage), and iv) a broadly defined "other" category (e.g. reducing company-printed materials, recycling office supplies and packaging materials, installing solar panels in warehouses). Pieters et al. (2012) investigate how changes in the 3PLs' sustainability strategies influenced the development of new types of physical distribution networks in the Dutch market. The authors surveyed 145 logistics companies that adopted 608 initiatives related to physical distribution. Four categories were derived: i) internal approach (actions organized by the logistics service provider/shipper), ii) external approach (initiatives which need cooperation with others outside the focal organization such as shippers, governments, competitors, stakeholders etc.), iii) innovating (initiatives previously unknown to the logistics service provider/shipper) and iv) optimizing (initiatives for improving efficiency). Results show that most of the adopted initiatives focused on internal approaches. Isaksson and Huge-Brodin (2013) investigated how the service offering is affected by green initiatives in six 3PL case companies operating in the Swedish market. Results indicated that initiatives to address green issues are in a different state of development among the case companies and three patterns were identified. The first focused on strategic standpoint of the greening of the 3PLs' activities and the competitive awareness of the development in the logistics market. The second involves customer orientation and the transfer and sharing of green knowledge and competences. The third concerns how green activities are managed and controlled within the company. The paper presented by Evangelista (2014) explores environmental sustainability practices in a sample of 13 Italian 3PLs and three groups of companies with different environmental strategies have been identified. This was done on the basis of a differing degree of involvement in green initiatives due to variations in the breadth of service offered and to the importance attributed to environmental issues. In this study a taxonomy distinguishing two different types of initiatives is proposed. On one hand, there are initiatives mainly focused on green solutions that have predominantly effects within the boundaries of the 3PL company (called "point" initiatives). On the other, there are green actions that extend their impact on different stages of the supply chain well beyond the boundaries of the 3PL company (called "supply chain" initiatives). Perotti et al. (2012) explore the relationship between green supply chain practices (GSCP) implementation and company performance through investigating 15 case companies. The authors identified 8 different categories of green supply chain practices (i.e. green supply, distribution strategies and transportation, warehousing and green building, reverse logistics, cooperation with customers, investment recovery, eco-design and packaging and internal management). Findings indicate that the adoption of GSCP is considerably low in the case companies. Colicchia at al. (2013) investigated the environmental report of ten 3PLs and three of them were in-depth interviewed. Findings allow the authors to classify the environmental actions implemented by the surveyed companies into two macro categories: "intra-organizational" practices (including distribution strategies and transportation execution, warehousing and green building, reverse logistics, packaging management and internal management) and "inter-organizational" practices (including collaboration with customers and external collaborations). Results show that initiatives related to distribution strategies and transportation activities are the most widely implemented, while initiatives involving internal management are not broadly adopted. Finally, Oberhofer and Fürst (2013) investigate the impact of green measures on the performance of a sample of Austrian road transport companies. Results show that although stakeholders' attitudes 
significantly affect the companies' environmental performance, firm size and the industrial sector in which companies operate have greater influence. The work of Kellner and Igl (2015) studied the effects of the adoption of different logistics network designs on GHG emissions in the distribution phase. Results show that 3PLs using a geographically decentralized consolidation of shipments are the most efficient in reducing GHG emissions. The papers analysed in this stream of literature provide a not well defined picture of green initiatives undertaken by 3PLs. Firstly, most studies focused on one single initiative (e.g. intermodal arrangements). Secondly, it is still unclear the breadth of the impact of such initiatives. In particular, most papers included in the analysis do not clarify if the investigated actions have their main effect within the boundaries of the company only. Thirdly, the vast majority of papers investigated large 3PLs. Taking into account the above arguments, it is possible to formulate the following research question:

RQ2) What green initiatives (point or supply chain) are adopted by 3PLs?

\subsection{Influencing factors}

The implementation of green initiatives is generally influenced by a number of factors, which may hinder or accelerate the adoption of such initiatives ( $\mathrm{Li}$ et al., 2015). It is possible to divide these factors (i.e. drivers and barriers) into two groups, namely internal and external. Internal factors have an impact within the company's boundaries and on its internal processes. External factors affect behaviour and decisions of the company within its supply chain and the system of relationships with players such as customers, suppliers, government and institutional bodies (Walker et al., 2008). In the specific area of 3PL research several efforts have already been made to identify determinants of green initiatives. The paper of Wong and Fryxell (2004) found that environmental management practices among fleet managers in Hong Kong is modestly influenced by stakeholders. The study of Lin and Ho (2008) analysed the factors influencing 3PLs' attitudes toward environmental management practices in a sample of Taiwanese logistics companies. Results indicate that the diffusion of knowledge within the company about green practices can raise the willingness to adopt green actions. Lieb and Lieb (2010b) found that customer pressures and corporate management environmental awareness are the most important factors influencing the adoption of green initiatives. Similarly, the survey carried out by Lin and Ho (2011) on a sample of 322 logistics service companies in China reveals that both internal (e.g. regulatory pressure and governmental support) and external (e.g. organizational support and quality of human resources) factors have a major influence in the implementation of green initiatives. Environmental uncertainty and the complexity of green practices have been found as relevant barriers to the adoption of an environmental management approach. The authors did not found a significant influence of customers on company's environmental sustainability attitude. On the contrary, Jumadi and Zailani (2010) found a positive influence of customer relationships on the adoption of green actions in the logistics service sector in Malaysia. Beskovnik and Jakomin (2010) identified long-term contracts as an important driver of the implementation of green measures by logistics companies. Maas et al. (2014) identified internal environmental communication as a relevant factor affecting the pollution prevention capabilities of 202 German 3PLs. Oberhofer and Dieplinger (2014) surveyed a set of seven 3PL Austrian case companies and identified a number of influencing factors such as the pressures coming from upstream actors in the supply chain, the structure of the logistics and transport sector 
and the importance of energy efficiency in the long run. Perotti et al. (2015) investigates motivations and barriers to the adoption of GSCP in a sample of 15 Italian 3PLs. The authors found that key motivations for adopting GSCP are environmental reputation and the need to establish a company green image. High investments, lack of interest of suppliers and customers in environmental sustainability and difficulties in identifying and measuring environmental performance have been identified as main barriers to GSCP implementation. The literature on influencing factors suggests that there is not a consistent and comprehensive assessment of the factors affecting 3PLs' decisions to undertake green actions. Firstly, from the works analysed it does not clearly emerge how factors exert their influence on the adoption of green initiatives. Secondly, while some papers focused on internal factors, other identified exclusively external factors. Only very few papers identified and investigated a mix of internal and external drivers and barriers. Finally, also in this stream of literature the papers mainly surveyed large 3PLs. Taking into account these arguments, it is possible to formulate the following research question:

RQ3) What are the main factors (internal and external drivers and barriers) affecting the adoption of green initiatives by 3PLs?

\section{RESEARCH DESIGN AND METHODOLOGY}

The investigation conducted in this research relied on a qualitative approach, i.e. multiple case studies. The case study methodology is well acknowledged to gain a deeper understanding of a phenomenon under development or whose dimensions are not yet fully understood (Yin, 2003). Additionally, a multiple case approach allows for the comparison of two or more business situations to support explorative investigations (Eisenhardt, 1989). Also, by enabling direct interaction with people and informants, case research provides an advantage over other research techniques, such as surveys, for the purposes of the present study (Miles and Huberman, 1994). Our research process combines the models proposed by Stuart et al. (2002) and Dul and Hak (2008): case selection, instrument development, data gathering, and data analysis. Prior to the description of each single step of the above model, an introduction to the research context in which the study has been developed is provided.

\subsection{The research context: the Italian and UK logistics service markets}

The Italian and UK logistics service markets are in the list of the top four European markets in terms of market value (Klaus and Kille, 2013). They show a similar modal split (i.e. great relevance of road transport) and a similar industry structure (i.e. majority of small and medium sized companies). The value of the Italian transport and logistics service industry is estimated at over $€ 80$ billion (Klaus and Kille, 2013). The EU Commission estimates that about 1 million people are employed in the sector by around 134,000 companies and a large proportion of firms are small and medium sized (European Commission, 2014). Road haulage is the most important contributor to the value of the sector. In Italy road transport accounted for almost $60 \%$ of total tonne-kilometres moved domestically in 2011 (Ministero delle Infrastrutture e dei Trasporti, 2012). The value of the UK logistics market is estimated at over $€ 90$ billion (Klaus and Kille, 2013) and it employs around 2.3 million people in more than 188,000 companies (AGCAS, 2012). The largest part of the companies is represented 
by small and medium-sized enterprises (European Commission, 2014). Approximately $73 \%$ of the total freight movements in the country take place through road transport (Department for Transport, 2016).

\subsection{Case selection}

The case selection process was aimed at creating a diverse but coherent universe for our exploration (Robinson, 2014). It was organised into two main phases: 1) identification of a preliminary set of companies and 2) application of selection criteria. In the first phase, a list of 3PLs was obtained using data gathered from the sources of information available in the respective countries. As for Italy, it was compiled using information provided by large Italian transport and logistics associations such as Confetra (http://www.confetra.it), Assologistica (http://www.assologistica.it/) and the Italian Freight Leaders Council (http://www.freightleaders.org/). As for the UK, we referred to public sources of information such as the Companies House databases (https://www.gov.uk/government/organisations/companies-house)

In the second phase, consistently with the focus and objectives of the research, the following three inclusion criteria were applied to define the target population:

a) Including companies that are explicitly engaged in environmental sustainability programmes and actions. This information was obtained through a number of secondary sources, i.e. company/environmental reports and company websites.

b) Including medium sized 3PL companies. As shown in the literature review, most of research conducted on the environmental sustainability in the 3PL industry is focused on large logistics companies.

c) Including 3PL companies with different ranges of services provided, spanning from pure haulage to value added logistics and SCM services.

Following the recommendations suggested by Ellram (1996), ten companies were included in the final sample (five Italian and five from the UK for a balanced sample). In fact, as argued by Yin (2003), six to ten cases should provide evidences to support or reject propositions, while Eisenhardt (1989) recommends four to ten cases. Our selection of ten cases fits well within these recommendations.

Table 1 provides the summary profile of the case companies included in the sample. For confidentiality reasons, the company names have not been disclosed and each company has been referred to by using the acronym of the country (IT or UK) followed by a sequential number.

Table 1. Summary profile of the case study companies

\begin{tabular}{|c|c|c|c|c|c|c|c|c|c|c|c|}
\hline & & IT1 & IT2 & IT3 & IT4 & IT5 & UK1 & UK2 & UK3 & UK4 & UK5 \\
\hline \multirow{5}{*}{$\begin{array}{l}\text { Services } \\
\text { provided }\end{array}$} & Transport & $\mathrm{x}$ & $\mathrm{x}$ & $\mathrm{x}$ & $\mathrm{x}$ & $\mathrm{x}$ & $\mathrm{x}$ & $\mathrm{x}$ & $\mathrm{x}$ & $\mathrm{x}$ & $\mathrm{x}$ \\
\hline & Warehousing & & $\mathrm{x}$ & $\mathrm{x}$ & $\mathrm{x}$ & $\mathrm{x}$ & $\mathrm{x}$ & $\mathrm{x}$ & & $\mathrm{x}$ & $\mathrm{x}$ \\
\hline & Distribution & & & & $\mathrm{x}$ & $\mathrm{x}$ & & $\mathrm{x}$ & $\mathrm{x}$ & & $\mathrm{x}$ \\
\hline & Value added services & & $\mathrm{x}$ & $\mathrm{x}$ & $\mathrm{x}$ & $\mathrm{x}$ & $\mathrm{x}$ & & & $\mathrm{x}$ & \\
\hline & SCM services & & & & & $\mathrm{x}$ & & & & & \\
\hline \multirow{2}{*}{$\begin{array}{l}\text { Transport } \\
\text { services }\end{array}$} & In-house & $\mathrm{X}$ & $\mathrm{x}$ & $\mathrm{x}$ & $\mathrm{x}$ & $\mathrm{x}$ & $\mathrm{x}$ & $\mathrm{x}$ & $\mathrm{x}$ & $\mathrm{x}$ & $\mathrm{x}$ \\
\hline & Outsourced & & $\mathrm{x}$ & & & $\mathrm{x}$ & $\mathrm{x}$ & & & $\mathrm{x}$ & \\
\hline \multirow{4}{*}{$\begin{array}{l}\text { Geographical } \\
\text { reach }\end{array}$} & Regional & & & & & & & & & & \\
\hline & National & & & & & & & & $\mathrm{x}$ & & $\mathrm{x}$ \\
\hline & Europe & $\mathrm{x}$ & $\mathrm{X}$ & $\mathrm{x}$ & $\mathrm{x}$ & & $\mathrm{x}$ & & & $\mathrm{x}$ & \\
\hline & Global & & & & & $\mathrm{x}$ & & $\mathrm{x}$ & & & \\
\hline ICT tools used & $\begin{array}{l}\text { Location-based } \\
\text { technology (EDI, GPS, }\end{array}$ & $\mathrm{x}$ & $\mathrm{x}$ & $\mathrm{x}$ & $\mathrm{x}$ & $\mathrm{x}$ & $\mathrm{x}$ & $\mathrm{x}$ & $\mathrm{x}$ & $\mathrm{x}$ & $x$ \\
\hline
\end{tabular}




\begin{tabular}{|l|l|l|l|l|l|l|l|l|l|l|l|}
\hline & bar code, RFID) & & & & & & & & & & \\
\hline $\begin{array}{l}\text { Connectivity tech (LAN, } \\
\text { WLAN) }\end{array}$ & $\mathrm{x}$ & & $\mathrm{x}$ & $\mathrm{x}$ & $\mathrm{x}$ & $\mathrm{x}$ & $\mathrm{x}$ & $\mathrm{x}$ & $\mathrm{x}$ & $\mathrm{x}$ \\
\hline $\begin{array}{l}\text { Relational tech (ERP, } \\
\text { CRM) }\end{array}$ & & & & $\mathrm{x}$ & & $\mathrm{x}$ & $\mathrm{x}$ & & $\mathrm{x}$ & $\mathrm{x}$ \\
\hline
\end{tabular}

\subsubsection{Instrument development}

A data collection guide (DCG) was developed, including a mixture of open and multiple choice questions. It comprises the following five main sections:

1. Company profile

2. Environmental sustainability culture and organizational actions

3. Adoption of green initiatives

4. Drivers of green initiatives

5. Barriers affecting green initiatives

A pilot test was performed with a panel of academics and experts in the field of green logistics and supply chain management before the full sample interviews. As a result, amendments were made on the wording of some of the questions so that they resulted clearer and more focused on the areas of interest. The pilot test allowed avoiding misinterpretations (Yin, 2003), providing a refined and solid DCG.

\subsubsection{Data gathering}

We identified the most suitable informants in each participating company: the managing director, the supply chain manager, and/or other professionals responsible for the environmental management. Interviews were performed at the company site and lasted approximately 1.5 hours each. They were audio recorded and transcribed to write interview reports for supporting data analysis. Reports and transcripts were included in a case study database. Company documents such as internal presentations, reports, and external documentation, as well as web sites were analysed to enable triangulation of information. The use of multiple respondents and different types of data was intended to mitigate the bias of single sources of information (Pagell and $\mathrm{Wu}, 2009)$. Interview reports were shared with the interviewees to ensure construct validity (Yin, 2003) and discrepancies were resolved by recalling respondents.

\subsection{Data analysis}

First, a within case analysis was performed with the aim to allow a structured thematic analysis (Crabtree and Miller, 1999). Within-case study reports were generated, shared with and reviewed by the informants (Yin, 2003). Subsequently, a cross case comparison was performed, in order to identify emergent patterns of commonalities and key differences (Ghauri, 2004).

\subsection{Assessment of empirical validity}

Construct validity was ensured through the involvement of multiple informants and by seeking feedback and observations from them (Yin, 2003). Internal validity was ensured through the development of the interview protocol and the structured analysis of the collected data, which helped in maintaining the chain of evidence (Yin, 2003). External validity was ensured by setting suitable sampling criteria, which allowed building a coherent and diverse sample. Sufficient variety within the boundaries of the sampling universe was allowed and details on the case companies were provided (Yin, 2003). Reliability of the research was ensured on the rigour of the applied process and on the level of detail provided, which allows for replicability of the study (Yin, 2003). 


\section{FINDINGS FROM THE CASE STUDIES}

This section is consistently arranged with the main focus areas of the research questions of this study: environmental sustainability culture and organizational actions, green initiatives, and drivers and barriers affecting their adoption.

\subsection{Environmental sustainability culture and organizational actions}

With reference to environmental sustainability culture (Table 2), within the Italian sub-sample it is possible to observe that companies IT2 and IT3 only do not consider environmental sustainability as a priority, while only IT5 has a formal and explicit strategy for environmental sustainability issues, which is also embedded in the overall business strategy. IT1 and IT4 have an informal and implicit environmental sustainability strategy, however recalled in the overall corporate strategy. The UK sub-sample shows a more consistent strong perception of environmental sustainability as a priority for companies, with a formal and explicit environmental sustainability strategy incorporated in the overall business strategy. The only exception is represented by UK4 that, notwithstanding the moderate importance attributed to environmental sustainability, does not make any reference to it in a published document and in the overall corporate strategy.

Table 2. Environmental sustainability culture

\begin{tabular}{|l|c|c|c|c|c|c|c|c|c|c|}
\hline $\begin{array}{l}\text { Environmental } \\
\text { culture }\end{array}$ & IT1 & IT2 & IT3 & IT4 & IT5 & UK1 & UK2 & UK3 & UK4 & UK5 \\
\hline $\begin{array}{l}\text { Priority } \\
\text { attributed to } \\
\text { environmental } \\
\text { sustainability }\end{array}$ & Medium & Low & Low & High & High & high & high & high & medium & high \\
\hline $\begin{array}{l}\text { Formal Vs. } \\
\text { informal } \\
\text { environmental } \\
\text { strategy }\end{array}$ & $\begin{array}{c}\text { Informal } \\
\text { and } \\
\text { implicit }\end{array}$ & $\begin{array}{c}\text { Not } \\
\text { present }\end{array}$ & $\begin{array}{c}\text { Not } \\
\text { present }\end{array}$ & $\begin{array}{c}\text { Informal } \\
\text { and } \\
\text { implicit }\end{array}$ & $\begin{array}{c}\text { Formal } \\
\text { and } \\
\text { explicit }\end{array}$ & $\begin{array}{c}\text { Formal } \\
\text { and } \\
\text { explicit }\end{array}$ & $\begin{array}{c}\text { Formal } \\
\text { and } \\
\text { explicit }\end{array}$ & $\begin{array}{c}\text { Formal } \\
\text { and } \\
\text { explicit }\end{array}$ & $\begin{array}{c}\text { Not } \\
\text { present }\end{array}$ & $\begin{array}{c}\text { Formal } \\
\text { and } \\
\text { explicit }\end{array}$ \\
\hline $\begin{array}{l}\text { Environmental } \\
\text { strategy as a part } \\
\text { of the corporate } \\
\text { strategy }\end{array}$ & Yes & No & No & Yes & Yes & Yes & Yes & Yes & No & Yes \\
\hline
\end{tabular}

Table 3 summarises the findings of the organizational involvement in terms of primary and secondary responsibility for environmental issues.

Table 3. Organisational units responsible for environmental issues

\begin{tabular}{|l|c|c|c|c|c|c|c|c|c|c|}
\hline Organisational units & IT1 & IT2 & IT3 & IT4 & IT5 & UK1 & UK2 & UK3 & UK4 & UK5 \\
\hline Top management & $\mathrm{P}$ & $\mathrm{P}$ & $\mathrm{P}$ & & & $\mathrm{S}$ & $\mathrm{P}$ & $\mathrm{P}$ & $\mathrm{P}$ & $\mathrm{S}$ \\
\hline Logistics/SC dept & $\mathrm{S}$ & $\mathrm{S}$ & $\mathrm{S}$ & $\mathrm{P}$ & & $\mathrm{S}$ & $\mathrm{S}$ & $\mathrm{S}$ & & \\
\hline Environmental dept & n.a. & n.a. & n.a. & n.a. & $\mathrm{P}$ & n.a. & n.a. & n.a. & n.a. & P \\
\hline Marketing/sales dept & & & $\mathrm{S}$ & & $\mathrm{S}$ & & & & & \\
\hline Finance dept & & $\mathrm{S}$ & $\mathrm{S}$ & & & & & & & \\
\hline Purchasing dept & & $\mathrm{S}$ & $\mathrm{S}$ & & $\mathrm{S}$ & & & $\mathrm{S}$ & & \\
\hline IT-dept & $\mathrm{S}$ & $\mathrm{S}$ & $\mathrm{S}$ & & & & & & & \\
\hline Health \& Safety & & & & & & $\mathrm{P}$ & $\mathrm{S}$ & $\mathrm{S}$ & & $\mathrm{S}$ \\
\hline
\end{tabular}

Key: $\mathbf{P}=$ primary responsibility; $\mathbf{S}=$ secondary responsibility

It is possible to observe that within the Italian sub-sample companies IT2 and IT3 show a shared responsibility across several organizational units, while IT1, IT4 and 
IT5 show a more concentrated responsibility. In particular, only the Logistics/SC Department are responsible for environmental sustainability in IT4 and IT5 only has a dedicated Environmental Department. The UK sub-sample shows in general a more concentrated responsibility. In companies UK2, UK3 and UK4 the top management has the primary responsibility. UK5 has a dedicated Environmental Department, while in UK1 the Health and Safety department own the primary responsibility.

\subsection{Adoption of green logistics initiatives}

Table 4 summarises the findings on green initiatives implemented by each case company.

IT1 predominantly adopted initiatives focused on vehicle use and aimed at reducing empty running/improving vehicle loading. The company also adopts actions related to the choice of low energy transport modes and intermodal transport, energy efficiency, recycling materials and packaging, and employee training. This company shows a limited sensitivity towards environmental aspects as it adopts an approach mainly based on cost efficiency Most of the actions undertaken by IT2 involve areas such as reducing empty running and improving vehicle loading, modal choice and intermodal transport, energy efficiency, recycling materials and packaging, and environmental training and information. It also provides information on carbon footprint. In addition IT2 is active in the area of supply chain re-organisation using transport planning systems and changes in the logistics system. The company also adopts an environmental management system (i.e. ISO 14001). The actions undertaken by IT3 and IT4 show an emphasis on actions involving environmental supply chain reorganisation, supply chain collaboration and collaborative planning and environmental control. Similarly, IT5 adopts these actions, within a very extensive approach to green initiatives that includes also emission off-set programs, supply chain collaboration and re-organisation initiatives, training and information sharing with customers on green logistics, and the planning of transport and loading for better sustainability.

Table 4. Green initiatives adopted by the case study companies

\begin{tabular}{|c|c|c|c|c|c|c|c|c|c|c|c|c|}
\hline & Area & Initiative & IT1 & IT2 & IT3 & IT4 & IT5 & UK1 & UK2 & UK3 & UK4 & UK5 \\
\hline & & $\begin{array}{l}\text { Changing vehicle } \\
\text { specifications }\end{array}$ & & & & $\mathrm{x}$ & & & $\mathrm{X}$ & $\mathrm{x}$ & & $\mathrm{x}$ \\
\hline & Vehicle use & $\begin{array}{l}\text { Reducing empty } \\
\text { running }\end{array}$ & $\mathrm{x}$ & $\mathrm{X}$ & $\mathrm{x}$ & $\mathrm{x}$ & $\mathrm{x}$ & $\mathrm{x}$ & $X$ & $\mathrm{x}$ & $\mathrm{x}$ & $\mathrm{x}$ \\
\hline & & $\begin{array}{l}\text { Improving } \\
\text { vehicle loading } \\
\text { phase }\end{array}$ & $\mathrm{x}$ & $\mathrm{X}$ & $\mathrm{x}$ & $\mathrm{x}$ & $\mathrm{x}$ & $\mathrm{x}$ & $\mathrm{X}$ & $\mathrm{x}$ & $\mathrm{x}$ & $\mathrm{x}$ \\
\hline$\overbrace{}^{0}$ & $\begin{array}{l}\text { Transport } \\
\text { modes and }\end{array}$ & $\begin{array}{l}\text { Using lower } \\
\text { energy transport } \\
\text { modes }\end{array}$ & $\mathrm{x}$ & $X$ & $\mathrm{x}$ & $\mathrm{x}$ & & $\mathrm{x}$ & $\mathrm{X}$ & & & \\
\hline 竞 & intermodality & $\begin{array}{l}\text { Greater use of } \\
\text { intermodality }\end{array}$ & $\mathrm{x}$ & & $\mathrm{x}$ & & & $\mathrm{x}$ & $X$ & & & \\
\hline 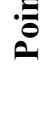 & $\begin{array}{l}\text { Energy } \\
\text { efficiency }\end{array}$ & $\begin{array}{l}\text { Renewable } \\
\text { energy (including } \\
\text { alternative fuels) }\end{array}$ & $\mathrm{x}$ & $\mathrm{X}$ & $\mathrm{x}$ & $\mathrm{x}$ & & $\mathrm{x}$ & $\mathrm{X}$ & $\mathrm{x}$ & $\mathrm{x}$ & \\
\hline & Recycling & $\begin{array}{l}\text { Increasing waste } \\
\text { recycled }\end{array}$ & & $\mathrm{X}$ & $\mathrm{x}$ & & & $\mathrm{x}$ & $\mathrm{X}$ & $\mathrm{x}$ & & $\mathrm{x}$ \\
\hline & $\begin{array}{l}\text { materiais and } \\
\text { packaging }\end{array}$ & $\begin{array}{l}\text { Reducing } \\
\text { packaging }\end{array}$ & & $\mathrm{X}$ & $\mathrm{x}$ & $\mathrm{x}$ & & & $X$ & & $\mathrm{x}$ & \\
\hline & $\begin{array}{l}\text { Warehousing } \\
\text { and green }\end{array}$ & $\begin{array}{l}\text { Eco-friendly } \\
\text { building design }\end{array}$ & & & & & & $\mathrm{x}$ & & $\mathrm{x}$ & $\mathrm{x}$ & $\mathrm{x}$ \\
\hline
\end{tabular}




\begin{tabular}{|c|c|c|c|c|c|c|c|c|c|c|c|c|}
\hline & \multirow[t]{3}{*}{ building } & $\begin{array}{l}\text { Energy-efficient } \\
\text { material handling } \\
\text { equipment }\end{array}$ & & & & & & $\mathrm{x}$ & $\mathrm{X}$ & $\mathrm{x}$ & $\mathrm{x}$ & $\mathrm{x}$ \\
\hline & & $\begin{array}{l}\text { Use of alternative } \\
\text { energy sources in } \\
\text { warehousing }\end{array}$ & & & $\mathrm{x}$ & $\mathrm{x}$ & $\mathrm{x}$ & & & & & \\
\hline & & Efficient land use & & & & & & & & & $\mathrm{x}$ & \\
\hline \multirow{10}{*}{ 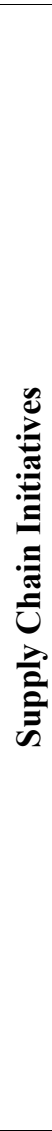 } & \multirow{3}{*}{$\begin{array}{l}\text { Environmental } \\
\text { training and } \\
\text { information }\end{array}$} & $\begin{array}{l}\text { Employee } \\
\text { training } \\
\text { (including eco- } \\
\text { driving and tyre } \\
\text { pressure } \\
\text { monitoring) }\end{array}$ & $\mathrm{x}$ & $\mathrm{X}$ & $\mathrm{x}$ & $\mathrm{x}$ & & $\mathrm{X}$ & & $\mathrm{x}$ & $\mathrm{x}$ & $\mathrm{x}$ \\
\hline & & $\begin{array}{l}\text { Customer/supplie } \\
\text { r training }\end{array}$ & & $X$ & & & $\mathrm{x}$ & $\mathrm{X}$ & & $\mathrm{x}$ & & $\mathrm{x}$ \\
\hline & & $\begin{array}{l}\text { Information on } \\
\text { carbon footprint }\end{array}$ & & $\mathrm{X}$ & & $\mathrm{x}$ & $\mathrm{x}$ & & & $\mathrm{x}$ & & \\
\hline & \multirow{2}{*}{$\begin{array}{l}\text { Supply Chain } \\
\text { re-organization }\end{array}$} & $\begin{array}{l}\text { Transport } \\
\text { planning } \\
\text { (including route } \\
\text { optimization) }\end{array}$ & & $\mathrm{X}$ & $\mathrm{x}$ & $\mathrm{x}$ & $\mathrm{x}$ & & $\mathrm{X}$ & $\mathrm{x}$ & $\mathrm{x}$ & $\mathrm{x}$ \\
\hline & & $\begin{array}{l}\text { Changes in } \\
\text { logistics system }\end{array}$ & & $\mathrm{X}$ & & $\mathrm{x}$ & $\mathrm{x}$ & & & $\mathrm{x}$ & $\mathrm{x}$ & $\mathrm{x}$ \\
\hline & \multirow{2}{*}{\begin{tabular}{|l|} 
Supply Chain \\
collaboration on \\
shared green \\
targets
\end{tabular}} & With customer & & & & & $\mathrm{x}$ & & $\mathrm{X}$ & & & $\mathrm{x}$ \\
\hline & & With other 3PLs & & & & & $\mathrm{x}$ & & $\mathrm{X}$ & & & \\
\hline & \multirow{3}{*}{$\begin{array}{l}\text { Collaborative } \\
\text { planning and } \\
\text { environmental } \\
\text { control }\end{array}$} & $\begin{array}{l}\text { Environmental } \\
\text { Management } \\
\text { System (ISO } \\
14001 \text { ) } \\
\end{array}$ & & $\mathrm{X}$ & $\mathrm{x}$ & $\mathrm{x}$ & $\mathrm{x}$ & $\mathrm{X}$ & & $\mathrm{x}$ & & $\mathrm{x}$ \\
\hline & & $\begin{array}{l}\text { Emission off-set } \\
\text { programs }\end{array}$ & & & & & $\mathrm{x}$ & & & & $\mathrm{x}$ & \\
\hline & & $\begin{array}{l}\text { Setting lower } \\
\text { GHG targets }\end{array}$ & & & $\mathrm{x}$ & & $\mathrm{x}$ & & & $\mathrm{x}$ & $\mathrm{x}$ & \\
\hline
\end{tabular}

UK1 concentrated on the adoption of initiatives mainly related to the increased environmental efficiency of transport, warehousing and distribution operations, showing awareness also of the opportunities offered by intermodal transport. This clearly reflects its close link to port operations, which offer the possibility to leverage intermodal port centric logistics. The training of employees is another top priority for UK1, along with the implementation of an Environmental Management System. Likewise, UK2 worked on enhancing the environmental efficiency of transport and warehousing operations. However, rather than focusing on the internal training of employees, they focus more on transport planning and supply chain collaboration on shared green targets initiatives together with customers and supply chain partners (e.g. subcontractors). UK3 has a comprehensive approach to environmental sustainability: focusing on vehicle use, energy efficiency, recycling, training and supply chain reorganization, with the specific aim to increase the overall efficiency of their activities. Furthermore, they are exploring the possibility to rely on intermodal transport with customers' specific solutions and port centric approaches. The only area not covered is related to supply chain collaboration on environmental sustainability. UK4, consistently with the core business of the company, focuses on the development of green solutions especially for the warehousing activities, which encompass also the re-design of its logistics network for improving their carbon footprint. Similarly to UK3, UK5 has a fairly comprehensive approach to environmental sustainability. UK5 
is pursuing the activation of collaborative initiatives with customers, co-design of eco-friendly unit loads and the reorganization of customers' supply network.

\subsection{Drivers affecting the adoption of green logistics initiatives}

Table 5 reports the results on the drivers affecting the adoption of green initiatives.

Table 5. Importance of drivers influencing the adoption of green initiatives

\begin{tabular}{|c|c|c|c|c|c|c|c|c|c|c|c|}
\hline & Drivers & IT1 & IT2 & IT3 & IT4 & IT5 & UK1 & UK2 & UK3 & UK4 & UK5 \\
\hline \multirow{5}{*}{ } & Cost reduction & 0 & ( & ( & 0 & 0 & 0 & 0 & 0 & 0 & 0 \\
\hline & $\begin{array}{l}\text { Green initiatives requested by } \\
\text { top management/strategic board }\end{array}$ & ( & O & $\mathrm{O}$ & (1) & (1) & O & O & O & ( & \\
\hline & $\begin{array}{l}\text { Increase of the company's } \\
\text { profitability }\end{array}$ & O & O & (1) & 0 & (1) & O & 0 & O & O & \\
\hline & Reduction of company risk & 0 & 0 & (1) & (1) & (1) & 0 & O & 0 & O & 0 \\
\hline & $\begin{array}{l}\text { Improvement of corporate image } \\
\text { on the market }\end{array}$ & O & O & (1) & & 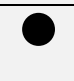 & O & O & 0 & (1) & \\
\hline \multirow{7}{*}{ 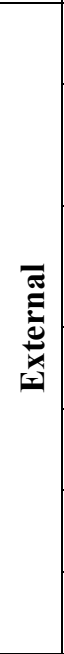 } & $\begin{array}{l}\text { Improvement of customer } \\
\text { relationships }\end{array}$ & O & (1) & & & O & O & O & O & 0 & \\
\hline & $\begin{array}{l}\text { Improvement of the overall } \\
\text { customer supply chain } \\
\text { effectiveness }\end{array}$ & O & $\mathrm{O}$ & & & 0 & 0 & (1) & (1) & 0 & (1) \\
\hline & $\begin{array}{l}\text { Green initiatives } \\
\text { implemented/requested by } \\
\text { customers }\end{array}$ & O & 0 & & & (1) & O & (1) & O & O & O \\
\hline & $\begin{array}{l}\text { Green initiatives implemented } \\
\text { by competitors }\end{array}$ & 0 & O & & & $\mathrm{O}$ & O & (1) & O & 0 & 0 \\
\hline & $\begin{array}{l}\text { Green initiatives implemented } \\
\text { by 3PLs partner }\end{array}$ & 0 & (1) & (1) & & 0 & 0 & (1) & 0 & (1) & 0 \\
\hline & $\begin{array}{l}\text { International, national, regional } \\
\text { or local regulations }\end{array}$ & 0 & 0 & (1) & (1) & (1) & 0 & 0 & 0 & (1) & 0 \\
\hline & $\begin{array}{l}\text { EU, national, regional } \\
\text { funding/economic incentives }\end{array}$ & 0 & & (1) & (1) & (1) & 0 & & 0 & & \\
\hline
\end{tabular}

Key: $\mathbf{O}=$ low importance; $\mathbf{O}=$ medium importance; $\boldsymbol{\bullet}=$ high importance

With reference to the Italian case companies, IT1 indicated that one external driver, i.e. governmental support, was the most influential affecting the adoption of green initiatives together with another external driver, i.e. the initiatives implemented by competitors. Also an internal driver was identified as very relevant, i.e. the support of management and the entrepreneur/owner. In addition to government, management and entrepreneurial support, IT2 indicated that external drivers such as the increasing level of green commitment of customers were considered as a stimulator of sustainability actions. Similar priority factors were identified by IT3 and IT4, which indicated external drivers as the most influential: green initiatives implemented by customers and competitors. These companies are focused on maintaining/improving relationships with customers and for this reason they pay great attention to customer sustainability programmes. Also, the actions undertaken by competitors are considered as a further incentive to adopt sustainability initiatives. IT5 shares the same views about the importance of the customer-facing side, while low importance is given to the competitors' actions and high relevance is allocated to the internal cost reduction. Taking into account the UK's sub-sample, companies UK2, UK3, UK4 and UK5 stressed the importance of internal drivers such as environmental sustainability as a lever for compressing operations' cost and for increasing company profitability 
along with the possibility to improve the company's image. Taking into account external drivers, it appears that all UK companies agreed on the great importance of green logistics initiatives for improving customer relationships. Medium/high importance is also given to the improvement of supply chain effectiveness as an external driver. On the other hand, the UK sub-sample seemed aligned on the low importance given to the competitors' initiatives as a trigger for going green. Interestingly, UK1, UK3, UK4 and UK5 see green initiatives as a lever for reducing company's risk -to cope with unexpected changes in regulations and increased competition. External funding is seen as an important driver by UK2, UK4 and UK5, while UK1 and UK3 judge this driver as not important. Regulations are seen as important by UK2 and UK3, while requests coming from the top management are seen as relevant by UK1 and UK5. Together with IT4, UK1 is the only company judging relevant also the actions undertaken by $3 \mathrm{PL}$ partners.

\subsection{Barriers preventing the adoption of green logistics initiatives}

Similarly to the drivers, internal and external barriers were distinguished (Table 6). Starting from the Italian sub-sample, for IT1 the most important barriers were both internal and external to the company. The high level of green investment and uncertainty about payback times are considered the main constraints limiting the development of green measures by this company. The lack of well-defined regulatory frameworks, customers' environmental awareness and financial incentives are the most influential external barriers. IT2 indicated external barriers, i.e. the lack of a well-defined regulatory framework, financial incentives and insufficient human resources, as the most influential ones causing the slow-down of green initiatives. Likewise IT3 and IT4 emphasised the lack of well-defined environmental regulations. However, these companies see also internal barriers such as the lack of human resources and ICT skills as two main elements that may hinder the adoption of green actions. IT5 indicated investment costs and payback of initiatives as the most influential barriers, but interestingly no other barriers (except from the medium ranked lack of human resources) are seen as relevant.

Table 6. Importance of barriers preventing the adoption of green initiatives

\begin{tabular}{|c|c|c|c|c|c|c|c|c|c|c|c|}
\hline & Barriers & IT1 & IT2 & IT3 & IT4 & IT5 & UK1 & UK2 & UK3 & UK4 & UK5 \\
\hline \multirow{4}{*}{ 胥 } & $\begin{array}{l}\text { High investment costs and lack of } \\
\text { financial resources }\end{array}$ & 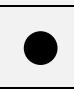 & 0 & (1) & (1) & $\Omega$ & 0 & 0 & 0 & 0 & \\
\hline & $\begin{array}{l}\text { Doubtful payback about green } \\
\text { investment }\end{array}$ & & 0 & (1) & 0 & 0 & 0 & (1) & 0 & (1) & \\
\hline & $\begin{array}{l}\text { Lack of human resources in green } \\
\text { initiatives }\end{array}$ & (1) & 0 & 0 & $C$ & (1) & 0 & 0 & 0 & 0 & \\
\hline & $\begin{array}{l}\begin{array}{l}\text { Lack of ICT skills for managing } \\
\text { green initiatives }\end{array} \\
\end{array}$ & 0 & 0 & & & 0 & & 0 & 0 & 0 & D \\
\hline \multirow{4}{*}{ } & $\begin{array}{l}\text { Lack of customers environmental } \\
\text { awareness }\end{array}$ & & 0 & (1) & 0 & 0 & 0 & 0 & 0 & 0 & \\
\hline & \begin{tabular}{|l|} 
Lack of 3PL partner \\
environmental awareness
\end{tabular} & & (1) & (1) & & 0 & 0 & (1) & 0 & (1) & 0 \\
\hline & $\begin{array}{l}\text { Lack of funding/economic } \\
\text { Incentives }\end{array}$ & & 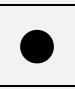 & (1) & (1) & 0 & & & 0 & 0 & 0 \\
\hline & $\begin{array}{l}\text { Lack of well-defined } \\
\text { regulations }\end{array}$ & & & & & 0 & & & 0 & 0 & 0 \\
\hline
\end{tabular}

Key: O = low importance; $\mathbf{O}=$ medium importance; $\mathbf{O}=$ high importance 
The companies belonging to the UK's sub-sample highlight the high investment costs, lack of financial resources and the doubtful payback about green investment as the main barriers. Except for UK5, medium/low importance is given to the lack of internal human and ICT skills, as well as to the lack of external customers' and 3PL partners' environmental awareness. UK2 and UK5 are the only companies recognising the lack of customers' environmental awareness as an important barrier. However, the companies are willing to further foster the adoption of green logistics initiatives in the extended supply chain, especially with customers. The UK's subsample provides different views regarding the lack of funding and economic incentives, and the lack of well-defined regulations.

\section{DISCUSSION OF THE FINDINGS}

The discussion of the findings allowed providing an answer to the research questions of this study.

As far as RQ1 (i.e. how do 3PLs embed environmental sustainability in their culture and organisation?) is concerned, no shared and uniform approach to embed environmental sustainability in the 3PLs' culture and organisation emerged. The majority of sample firms attribute high priority to environmental sustainability, especially in the UK sub-sample. The Italian companies show a lower level of priority attributed to environmental sustainability. This may be due to the fierce competition in the Italian logistics service market where price and cost efficiency are competitive leverages that have a prominent role in shaping companies' organizational culture. Hence, environmental sustainability has a lower level of priority per se: it can be seen as a way for reducing costs, with environmental benefits as a positive by-product. Thus, environmental sustainability lags behind and investments in green programs are delayed if not connected to economic benefits (Evangelista, 2014).

In relation to the formalisation of the environmental strategy, our results allow identifying different approaches: from an absent strategy to a formal and explicit one. It seems that at least a medium priority is necessary to have a recognisable environmental strategy, while acknowledging the importance of environmental sustainability is not always enough to develop an environmental strategy, as shown by UK4. A high priority attributed to environmental issues does not always imply the presence of a formal and explicit strategy, as for the case of IT4. Hence, our results lead to consider that, for medium-sized companies, a strong link between the values and perceptions of companies and their actual strategy is not always evident. This is in contrast with extant literature that documented how large 3PLs show more consistency in this sense (Lieb and Lieb, 2010a). Different approaches are also observed for the inclusion of the environmental strategy in the overall corporate strategy. Results suggest that this is not constrained to the existence of a formal and explicit environmental strategy.

A clear relationship between the environmental culture and the implemented organizational actions did not emerge. Top management almost always has primary responsibility, and this seems to lead to a formal and explicit environmental strategy in the UK sub-sample, while in the Italian sub-sample this is not happening (see IT2 and IT3). The Logistics or Supply chain department does not have a primary responsibility (excluding IT4) and this organizational unit has generally secondary responsibility for the environmental issues across the sample. Only two companies (IT5 and UK5) have a dedicated Environmental department. Consequently, it would seem that for medium-sized 3PLs an organizational function specifically dedicated to green issues exists when the environmental sustainability culture is sufficiently 
widespread and leads to the establishment of a formal and explicit strategy. In the UK sub-sample four companies out of five have an involvement of the Health \& Safety department in the management of environmental issues, with UK1 allocating primary responsibility to it. This is something typical to the UK, where environmental issues are associated to safety from a risk-management perspective.

As far as RQ2 is concerned (i.e. what green initiatives (point or supply chain) are adopted by 3PLs?), results allow identifying three different clusters of companies: companies adopting mainly "point" initiatives; companies adopting mainly "supply chain" initiatives and companies adopting a balanced set of measures including "point" and "supply chain" initiatives. Four companies populate the "point" cluster (IT1, IT3, UK1, UK2), five organisations populate the "balanced" cluster (IT2, IT4, UK3, UK4, UK5), and only one company populates the "supply chain" cluster (IT5). This is in line with the works of Pieters et al. (2012) and Lieb and Lieb (2010a). Looking at the implemented actions, the UK companies are more focused on "point" initiatives than the Italian ones. It seems also that the adoption of "supply chain" collaborative initiatives is underdeveloped in both sub-samples. By crossing the findings related to RQ1 and the clusters abovementioned a mixture of approaches emerges across the sample. In particular, companies without an environmental strategy and with low-medium priority attributed to environmental sustainability belong to the "point" cluster (IT3) or to the "balanced" cluster (IT2 and UK4). In other words, it appears that regardless their stated little interest in environmental sustainability, they adopt a narrow or also a wide range of green initiatives - that in some cases spans beyond the boundaries of the focal firm. On the other hand, companies stating considerable interest in environmental sustainability translated into the presence of an environmental strategy, belong to the "supply chain" cluster (IT5), to the "balanced" cluster (IT4 and UK3) and also to the "point" cluster (IT1, UK1 and UK2). It appears that companies claiming substantial involvement in green logistics adopt a wide range of initiatives, but in some cases focus their actions on a limited breadth of initiatives only. This constitutes interesting evidence: across the sample it is not possible to find clear common patterns, representing similar cultural and organizational approaches that lead to a similar deployment of the strategy in terms of green initiatives in medium-sized 3PLs. An aspect that could explain the above is the relationship among the range of service supplied and the type of actions undertaken. It may be assumed that 3PLs providing a wider breadth of services tend to adopt more collaborative initiatives involving multiple supply chain actors. However, from our results a clear connection among these factors does not emerge. Our evidence show that 3PLs providing different ranges of services share anyway similar attitudes towards environmental sustainability. This suggests that the attitude toward a more sophisticated environmental approach of medium-sized 3PLs isn't directly influenced by the range of the services supplied or their environmental culture and organization.

Another aspect that might be considered to explain the different approaches by companies is the connection between the adoption of green initiatives and their policy towards the outsourcing of transport services. From our results, it seems that keeping transport services in-house enables companies to adopt actions on their fleet of vehicles (IT4, UK2, UK3 and UK5). Instead, it seems that companies also outsourcing transport services to contract carriers or 3PL partners do not undertake those initiatives, as these would probably have only a limited effect on the sustainability of the offered transport services in the overall supply chain. It is also possible to notice that this group of companies does not adopt collaboration initiatives on shared green targets with 3PL partners, and this is something that could be 
expected given their decision to outsource part of their transport services. Only IT5 collaborates with partners on green targets, but this could be connected to the "supply chain" approach they have towards the adoption of green initiatives in general. Again, it seems that the policy towards the outsourcing of transport services does not affect the breadth of the undertaken initiatives, especially when interactions with 3PL partners are concerned.

As far as RQ3 is regarded (i.e. what are the main factors affecting the adoption of green initiatives by 3PLs?), by observing the overall set of drivers, it emerges that national and international regulations are a common driver in both sub-samples, in line with the extant literature (e.g. Tacken et al., 2014). Internal drivers are perceived as more important by the UK's companies, while external drivers affect more the development of green initiatives of the Italian companies. Drivers such as cost reduction and improvement of customer relationships seem to be common to the majority of the sample companies; these drivers are traditionally among the ones leading companies to foster the adoption of green logistics initiatives, as suggested by Lieb and Lieb (2010a) and Evangelista (2014). Another driver influencing the adoption of green initiatives of the UK's companies is the need to improve the corporate image. This can be related to the higher priority attributed to environmental sustainability as part of their company's strategy to enhance their image and competitiveness in the long run as suggested by Pålsson and Kovács (2014).

An overview of the barriers to the adoption of green logistics initiatives reveals that all companies perceive the lack of funding, economic incentives and of well-defined regulations as major inhibitors (Oberhofer and Dieplinger, 2014).

Finally, from our results the key role potentially played by customers in driving the implementation of green logistics initiatives of the Italian companies emerges. When customers have a high level of environmental awareness, they can drive initiatives to increase the environmental sustainability of the supply chain. On the other hand, customers are perceived as a barrier when their level of environmental awareness is low and they do not require/expect the development of green logistics actions by 3PLs.

\section{CONCLUSIONS AND IMPLICATIONS FOR THEORY AND PRACTICE}

The present paper addressed the topic of environmental strategies of a sample of 10 medium-sized 3PLs operating in Italy and in the UK.

From a theoretical perspective, this paper enriches the existing body of knowledge through a novel perspective, i.e. the focus on environmental strategies intended as the environmental organisational culture, the set of initiatives and factors influencing their implementation. Our discussions allowed answering the "main" question of this paper, i.e. is environmental sustainability a strategic priority for logistics service providers? For medium-sized 3PLs, the answer is "not always and not clearly". In fact our results lead to the conclusion that there is no uniform awareness of the environmental sustainability importance, and there isn't a clear and well-defined approach to the deployment of an environmental sustainability strategy. Environmental sustainability is something that is recognized by medium-sized 3PLs but that is not fully and consistently integrated in their mission, values and actions.

A number of implications for 3PL managers stand out from this study. While the importance attributed to environmental sustainability is generally recognised, consistent directions in the practices adopted by medium-sized 3PLs are not yet evident. Companies are able and willing to invest in environmental sustainability programmes if these programmes promise to deliver clear benefits. The suggestion is 
to conduct a careful analysis of current and future needs in terms of implementation of green actions, linking them to the overall company strategy, the cultural and organizational elements and the empowerment of human resources. When environmental sustainability is recognized as a strategic priority, the recommendation is to integrate it in the service offering. This may improve the visibility and reputation of 3PLs on the market, and it may provide an opportunity for differentiating their offering from competitors, reducing the effect of price competition.

This study provides insights for developing further research. Additional studies are needed to investigate the relationships between the set of implemented measures and the consequent outcomes. This should be done taking into account also the impact that single influencing factors have in steering the set of implemented measures. This should include also customers, which from our results seem to considerably influence the environmental strategy of medium-sized 3PLs. Further research efforts are also needed to investigate the relationship among the policies related to transport services (in-house or outsourcing) and the adoption of green initiatives at a supply chain level. This is important to better understand the allocation of the environmental impact to different supply chain partners and to improve the control of sustainability in the supply chain.

This study presents some limitations. The main relates to the small number of case companies investigated. To achieve an empirical generalisation it would be necessary to increase the number of case studies, and to carry out a wider survey. Another limitation concerns the focus of this study on medium sized companies only. For a more comprehensive understanding of the phenomenon investigated it may be worthwhile to include in further studies 3PLs of different sizes, encompassing also the implications related to the companies' ownership and the level of involvement of families in their management.

\section{REFERENCES}

AGCAS 2012. Industry Insight - Transport and Logistics. June 2012.

Argon-Correa JA, Hurtado-Torres N, Sharma S, Garcia-Morales V.J. 2008. Environmental strategy and performance in small firms: a resource-based perspective. Journal of Environmental Management. 86(1): 88-103.

Beskovnik B., Jakomin L. 2010. Challenges of green logistics in southeast Europe. Promet-Traffic \& Transportation. 22(2): 147-155.

Colicchia C., Marchet G., Melacini M. Perotti S. 2013. Building environmental sustainability: empirical evidence from Logistics Service Providers. Journal of Cleaner Production. 59: 197-209.

Crabtree B.F., Miller W.L. 1999. Using codes and code manuals: a template organizing style of interpretation. In Crabtree B.F. and Miller W.L. (Eds), Doing Qualitative Research, $2^{\text {nd }}$ ed., Sage, Newbury Park, CA.

Department for Transport. 2016. Transport Statistics Great Britain 2015, Publication Office of the Department for Transport UK.

Dul J., Hak T. 2008. Case study methodology in business research, Amsterdam: Butterworth-Heinemann.

Eisenhardt K.M. 1989. Building theories from case study research. Academy of Management Review. 4(4): 532-550.

Ellram L.M. 1996. The use of the case study method in logistics research, Journal of Business Logistics. 17(2): 93.

European Commission. 2014. EU transport in figures. Statistical pocketbook 2014. Publications Office of the European Union, Luxembourg. 
Evangelista P. 2014. Environmental sustainability practices in the transport and logistics service industry: An exploratory case study investigation. Research in Transportation Business and Management. 12: 63-72.

Fürst E., Oberhofer P. 2012. Greening road freight transport: evidence from an empirical project in Austria. Journal of Cleaner Production. 33: 67-73.

Ghauri P. 2004. Designing and conducting case studies in international business research. In Marschan-Piekkari R., Welch C. (Eds), Handbook of Qualitative Research Methods for International Business, Edward Elgar Publishing, Cheltenham.

Gotschol, A., De Giovanni, P., Esposito Vinzi, V. 2014. Is environmental management an economically sustainable business?. Journal of Environmental Management. 144(1):73-82.

Isaksson K., Huge-Brodin M. 2013. Understanding the efficiencies behind logistics service providers' green offerings. Management Research Review. 36(3): 216-238.

Jumadi H., Zailani S. 2010. Integrating green innovation in logistics service towards logistics services sustainability: a conceptual paper. Environmental Research Journal. 4(4): 261-271.

Kellner F., Igl, J. 2015. Greenhouse gas reduction in transport: analyzing the carbon dioxide performance of different freight forwarder networks. Journal of Cleaner Production. 99: 177-191

Klassen R.D., McLaughlin C.P. 1996. The Impact of Environmental Management on Firm Performance. Management Science. 42(8): 1199-1214.

Klaus P., Kille C. 2013. Top 100 in European Transport and Logistics Services, Deutscher Verkehrs-Verlag, Hamburg.

Lammgard C. 2012. Intermodal train services: A business challenge and a measure for decarbonisation for logistics service providers. Research in Transportation Business \& Management. 5: 48-56.

Li, J., Pan, S. Y., Kim, H., Linn, J. H., Chiang, P. C. 2015. Building green supply chains in eco-industrial parks towards a green economy: Barriers and strategies. Journal of Environmental Management. 162 (1): 158-170.

Lieb K.J., Lieb R.C. 2010a. Environmental sustainability in the third-party logistics (3PL) industry. International Journal of Physical Distribution and Logistics Management. 40(7): 524-533.

Lieb, R.C., Lieb, K.J. 2010b. The North American third-party logistics industry in 2008: the providers CEO perspective. Transportation Journal. 49(2): 53-65.

Lin C.Y., Ho Y.H. 2008. An empirical study on logistics service providers' intention to adopt green innovations. Journal of Technology Management \& Innovation. 3(1): 17-26.

Lin C.Y., Ho Y.H. 2011. Determinants of Green Practice Adoption for Logistics Companies in China. Journal of Business Ethics. 98: 67-83.

Lun V.Y.H., Lai, K.H, Wong, C.W.Y., Cheng, T.C.E. 2015. Greening propensity and performance implications for logistics service providers. Transportation Research Part E: Logistics and Transportation Review. 74(1): 50-62.

Maas S., Schuster T., Hartmann E. 2014. Pollution prevention and service stewardship strategies in the third-party logistics industry: Effects on firm differentiation and the moderating role of environmental communication. Business Strategy and the Environment. 23(1): 38-55.

McKinsey. 2013. The business of sustainability. Report McKinsey. Summer 2012. New York. NY. 
McWilliams A., Siegel D.S. 2011. Creating and capturing value: strategic corporate social responsibility, resource-based theory and sustainable competitive advantage. Journal of Management. 37(5): 1480-1495.

Min H., Kim I. 2012. Green supply chain research: past, present, and future. Logistics Research. 4(11): 39-47.

Ministero delle Infrastrutture e dei Trasporti. 2012. Conto Nazionale delle Infrastrutture e dei Trasporti - Anni 2010-2011. Dipartimento per i Trasporti, la Navigazione ed i Sistemi Informativi e Statistici, Direzione Generale per i Sistemi Informativi. Statistici e la Comunicazione. Ufficio di Statistica. Rome. Italy (in Italian).

Oberhofer P., Dieplinger M. 2014. Sustainability in the Transport and Logistics Sector: Lacking Environmental Measures. Business Strategy and the Environment. 23: 236-253.

Oberhofer P., Fürst E. 2013. Sustainable Development in the Transport Sector: Influencing Environmental Behaviour and Performance. Business Strategy and the Environment. 22(6): 374-389.

Pagell M., Wu Z. 2009. Building a more complete theory of sustainable supply chain management using case studies of 10 exemplars. Journal of Supply Chain Management. 45(2): 37-56.

Pålsson H., Kovács G. 2014. Reducing transportation emissions: A reaction to stakeholder pressure or a strategy to increase competitive advantage. International Journal of Physical Distribution \& Logistics Management. 4(4): 283-304.

Perotti S., Micheli G.J.L., Cagno E. 2015. Motivations and barriers to the adoption of green supply Chain practices among 3PLs. International Journal of Logistics Systems and Management. 20(2): 179-198.

Perotti S., Zorzini M., Cagno E., Micheli G.J.L. 2012. Green supply chain practices and company performance: the case of 3PLs in Italy. International Journal of Physical Distribution \& Logistics Management. 42(7): 640-672.

Pieters R., Glockner H.H., Omta O., Weijers, S. 2012. Dutch logistics service providers and sustainable physical distribution: searching for focus. International Food and Agribusiness Management Review. 15: 107-126.

Robinson O.C. 2014. Sampling in Interview-Based Qualitative Research: A Theoretical and Practical Guide. Qualitative Research in Psychology. 11(1): 25-41.

Rondinelli D., Berry, M. 2000. Multimodal transportation, logistics, and the environment: managing interactions in a global economy. European Management Journal. 18(4): 398- 410.

Rossi S. Colicchia C., Cozzolino A., Christopher M. 2013. The logistics service providers in eco-efficiency innovation: An empirical study. Supply Chain Management: An International Journal. 18(6): 583-603.

Stuart I., McCutcheon D., Handfield R., McLachlin R., Samson, D. 2002. Effective case research in operations management: A process perspective. Journal of Operations Management. 20: 419-433.

Tacken J., Rodrigues V.S., Mason, R. 2014. Examining CO2e reduction within the German logistics sector. International Journal of Logistics Management. 25(1): 5484.

Walker H., Di Sisto L., McBain D. 2008. Drivers and barriers to environmental supply chain management practices: Lessons from the public and private sectors. Journal of Purchasing and Supply Management. 14(1). 
Wan Ahmad, W. N. K., Rezaei, J., Tavasszy, L. A., de Brito, M.P. 2016. Commitment to and preparedness for sustainable supply chain management in the oil and gas industry. Journal of Environmental Management. 180 (15): 202-213.

WEF. 2009. Supply chain decarbonisation. The role of logistics and transport in reducing supply chain carbon emissions. World Economic Forum. Geneva. Switzerland.

Wolf C., Seuring S. 2010. Environmental impacts as buying criteria for third party logistical services. International Journal of Physical Distribution \& Logistics Management. 40(1): 84-102.

Wong L.T., Fryxell G.E. 2004. Stakeholder influences on environmental management practices: a study of fleet operations in Honk Kong (SAR), China. Transportation Journal. 43(4): 22-35.

Wu T., Wu Y.-C.J. Chen Y.J., Goh M. 2014. Aligning supply chain strategy with corporate environmental strategy: A contingency approach. International Journal of Production Economics. 147: 220-229.

Yin R.K. 2003. Case Study Research: Design and Methods. 3rd edition. Sage Publications. Thousand Oaks. IL

Zhu, Q., Sarkis, J., Lai, K. 2007. Initiatives and outcomes of green supply chain management implementation by Chinese manufacturers. Journal of Environmental Management. 85 (1): 179-189.

Zhu Q., Sarkis J., Cordeiro J., Lai, K.-H. 2008. Firm-level correlates of emergent green supply chain management practices in the Chinese context. Omega: The International Journal of Management Science. 36(4): 577-591. 